\title{
Heritage and urban renewal in Dundee: Learning from the past when planning for the future of a post-industrial city
}

Received (in revised form): 4 October 2007

\section{Catherine Di Domenico}

is Professor of Social Development and Director of Postgraduate Research Degrees at the University of Abertay, Dundee. She has conducted research on socio-economic development issues, with a particular focus on both West Africa and Scotland.

\section{Marialaura Di Domenico}

is Lecturer in Organisational Behaviour at the Open University Business School. Her research interests include industrial organisational heritage and urban identities.

\begin{abstract}
This paper explores the use of maritime heritage tourism as a tool for regenerating the post-industrial city of Dundee in relation to its history and to present efforts of re-imaging. Although Dundee has historically benefited from its proximity to the River Tay, since its demise as a port, regeneration strategies so far embraced have tended to focus on the centre, and in particular the development of retail and latterly, the city's new 'cultural quarter'. A new phase in urban renewal has brought about increased interest in the waterfront area which seeks to extend the existing focal point further east down the riverside beyond that of the Discovery Point Heritage Centre which showcases Captain Scott's ship ‘The Discovery' as Dundee's main maritime visitor attraction and a key part of the city's former brand campaign as 'City of Discovery'. The city has opted for a multifaceted strategy of development that includes a broader focus on leisure rather than solely heritage tourism per se, perhaps in recognition of the city's inability to establish a buoyant tourism base. Drawing upon original qualitative research, the paper critiques the approach being adopted and analyses the relationship between maritime heritage and a broader emphasis on leisure development. It assesses whether this is likely to promote a sustainable initiative of urban vibrancy and renewal rather than the present reality of a former industrial city in decline.
\end{abstract}

Catherine Di Domenico School of Social and Health Sciences

University of Abertay Dundee DD1 1 HG, UK Tel: + 44 (o) 1382308720 Fax: + 44 (o) 1382308749 E-mail: bstcmd@abertay.ac.uk

\section{Keywords:}

Heritage, maritime, regeneration, urban renewal

Journal of Retail and Leisure Property (2007) 6, 327-339. doi:10.1057/palgrave.rlp.5100074 


\section{INTRODUCTION ${ }^{1}$}

'Certain elements in the Scottish past have suffered particular violence ... some aspects are particularly distorted, while others, which should be prominent, hardly figure at all.'2

Dundee suffered from continuous economic decline in the latter decades of the 20th century. The last jute factories traditionally associated with the city had by then closed down along with other related industries. In the late 1980s and 1990s, policy makers in Dundee adopted various strategies to promote the city. For example, they began investing in the three ' $T$ 's of teaching, tourism and technology, due to the decline in importance of the formerly dominant three 'J's of jute, jam and journalism for which the city had become famous. The 'Dundee Project', first launched in 1981 was aimed at saving the city from cumulative social and economic decline by fundamentally changing its image. This strategy looked to Dundee's past, but in so doing embraced the city's maritime rather than its industrial heritage as a base upon which to build its regeneration. The 'Dundee Project' in 1991 evolved into the 'Dundee Partnership', a joint initiative responsible for city and community planning among the key agencies of the Dundee City Council, Scottish Enterprise Tayside, Tayside Police and NHS Tayside. This was followed by a promotional campaign for the city that was to brand it as the 'City of Discovery'. This brand name was derived from Captain's Scott's ship, the 'Discovery', which was built in Dundee. The 'Discovery' was berthed in 1993 on Discovery Quay beside the purpose-built Discovery Point museum and heritage centre. This is now Dundee's main maritime visitor attraction and a key part of the city's former brand campaign as 'City of Discovery'. The attraction focuses on Dundee's 19th century shipbuilding past. It shows visitors also how the city became a major centre for whaling and furthermore had a large merchant fleet that was later to keep the town's industries supplied with raw materials. ${ }^{3}$

In 1993, at the same time as the 'Discovery' was being berthed, a bitter dispute was being enacted that was to lead to the final closure in Dundee of Timex, a multinational watch manufacturer with assembly plants based in the city. This conflict put the city's industrial decline into national headlines and was in stark contrast to the up-beat image being presented to the outside world in the same year by the mooring of the 'Discovery' at Discovery Quay. The Timex dispute marked the final stages of the decline in Dundee's manufacturing industries, resulting in high unemployment in the city, and an overall uncertain economic future for Dundee's citizens. The closure of Timex in Dundee was particularly significant from an economic perspective, given its role in providing employment in the area in the years following World War II. However, it had also been a symbol of hope for the city, giving it a new sense of industrial identity during the post-war period. Thus, the collapse of Timex in 1993 was important for Dundonians as a watershed event at the end of the 20th century. However, the Timex closure that year, just like the decline in the jute industry half a century earlier, must be considered within the context of Dundee's history. This shows that Dundonians are resilient in the face of such 
hardships, and since 1993, instead of despair following the closure of the Timex factory, there appears to have been a determined effort on the part of its citizens to save their city from further decline. This led in 1998 to the decision of the 'Dundee Partnership' to turn to the past for inspiration about the future and so to Dundee's history and sense of place as a port city. ${ }^{3}$ In so doing, they decided to examine the potential of the former port and Central Waterfront area for Dundee's renewal in the 21st century.

Most of the information included in this paper is based on ethnographic research conducted in Dundee between 1993 and 2006. This was both formalised through structured research, and opportunistic in terms of the residence of the researchers in the Dock Street area, which is located adjacent to the central waterfront, and their participation in the residents' association, the City Centre Community Council and other city centre associations and events. Information was also obtained from recent interviews with various Dundee city centre residents and government officials and through a search of the literature, which included the local and national press. From these interviews, we can say that decisionmakers in the city have been stimulated towards an increased commitment to the strategies involved in urban change and renewal in their efforts to take Scotland's former premier industrial city of the 19th and early 20th centuries successfully into the 21 st century. This strategy strongly embraces Dundee's maritime heritage as a tool for regenerating and renewing Dundee as a post-industrial city, including as a central focus the new vision of development for the waterfront. However, despite these efforts, it has not been easy to dismiss the bitterness of the industrial past from the consciousness of many Dundonians. In particular, the 1993 Timex dispute has been difficult to erase from their memories. There is indeed evidence that, as with the jute workers of an earlier era, the former Timex workers are not easily forgotten in Dundee. However, this can be seen in a positive light and their experiences should indeed not be easily dismissed for much can be learned from the recent industrial past when planning for the benefit of a different future. Hope of city renewal through the ambitious waterfront development project must therefore be set in the context of a city which, although still bruised by industrial decline, traumatic memories of the past and relative poverty, must still comprehend the lessons taught by its recent industrial history in order to move forward successfully.

\section{DUNDEE UNTIL WORLD WAR II: THE GROWTH AND DECLINE OF THE JUTE INDUSTRY}

Dundee is a city with an industrial history and culture, which can be traced back to 1763 when the linen industry began to expand and develop. This was soon followed by the jute industry, which dates back to the 1830s when it emerged as a spin-off from the already successful linen mills. Dundee developed into Scotland's industrial city 'par excellence' with the image of 'Juteopolis' that prevailed for most of the 20th century and with which its name is still inextricably linked., ${ }^{4,5}$ By 1905 'Dundee had an almost complete monopoly of British jute manufacture - and indeed consumed about a third of the jute imported into Europe. Its 
greatest days had been in the 1870s, but its magnates often owned and managed its Calcutta rivals' ${ }^{6}$ The population of Dundee grew correspondingly, doubling between 1850 and 1900 and standing at 160,000 by the end of the 19th century with approximately 40,000 workers being employed in the jute mills. ${ }^{7}$

With this influx of people looking for work, Dundee continued to experience a huge population growth and before the First World War around 55,000 people were employed in the linen and jute industries in the city. Ogilvy has described jute as a bonanza. 'As the Irish fleeing starvation crowded cheek by jowl with dispossessed Highlanders into the slums of the Overgate and Hawkhill, Dundee became a boisterous frontier town where the only thing lower than the average life expectancy was the cost of labour'. ${ }^{7}$ Poverty and hardship thus became the norm in Dundee and remained so not only in the 19th century but also in the 20th. However, the people of Dundee also developed a reputation for strength and resilience, both of which were necessary in order that they might eke out an existence in what was to become the most industrialised city in Scotland. Indeed, 'the poverty, even in good times, was appalling. In the bad times it was unimaginable'. ${ }^{7}$ A commentator stated that there was 'no town in the United Kingdom where men and women laboured under worse conditions than in Dundee' 8

The expansion of the industrial base in Dundee attracted not only workers into the area but also industrialists who were keen to set up businesses in the booming city. There were, of course, wide disparities in the standard of living between the 'jute barons' and other businessmen, who resided in affluent areas like Broughty Ferry, and the working population who took up residence in the slum housing of the city centre around the mill and port areas. During the Great War, Dundee suffered economic hardship due to its over-dependence on its one principal industry, jute. This continued after the war and consequently population growth slowed down in the period between the wars. Dundee's overdependence on a narrow industrial base was reflected in an economic, social and employment structure that was not in balance. The Depression of the 1920s and 1930s devastated the city, as there was a loss of markets and less demand for its products due to the global recession. Moreover, advances in technology in India added to the availability of cheap labour and resulted in the decline of the jute industry. Shipbuilding also declined due to diminishing demand for transporting goods and people. Dundee, still burdened by outdated technology, had to adapt to the changing conditions of the time, diversify and produce goods for new markets. The city had to change its image.

\section{INDUSTRIAL DUNDEE AFTER WORLD WAR II: A FOCUS ON THE TIMEX DISPUTE AND CLOSURE}

After World War II, with the collapse of the jute and jam industries, Dundee received Development Area Status. Under the terms of the Decentralisation of Industry Act (1945), it set up its first Industrial Estate with serviced sites and advanced factories to attract new industries to the city. Grants for machinery and other capital costs were also made 
available to those companies that were eager to take advantage of the financial incentives. ${ }^{9}$ Among firms that were attracted to Dundee in this era were several North American multinationals. They came not only for the regional development grants offered by central government but also due to the fact that costs were less than in North America and salaries were lower compared to other areas in the UK. Well-known North American multinationals attracted to Dundee included the US Time Corporation, as well as National Cash Registers (NCR) and other companies. They were to have an important impact on the local economy, offering Dundonians employment in light engineering and at the same time requiring correspondingly new technological skills from the workforce. The UK Time Company, which in 1954 changed its name to Timex, along with the other North American companies, provided not only employment in post World War II Dundee but also a sense of identity and hope for the future of the city. Approximately, 10,000 people, or about 12 per cent of Dundee's occupied population found employment in these companies and for the first time in Dundee's history employment in textiles was overtaken by employment in engineering. ${ }^{9}$ The post-war optimism was sustained throughout the 1960s. However, the 1970s saw an end to post-war growth throughout the country and Dundee suffered an economic crisis with a steady contraction of its manufacturing base along with a process of industrial and corporate restructuring. Over 6,000 jobs were lost in the first part of the 1970s mainly due to the closure of NCR's mechanical cash register production. Timex, which had continued to expand until the mid-1970s, also began to run down its workforce from 1976. Indeed, the increasing dependence in the 1960s and 1970s on a few multinationals in Dundee had placed these organisations in a position of power, with disastrous consequences for the local economy when Timex, a prominent company among them, decided to change its strategies and look to manufacture its products in areas such as Southeast Asia where labour was cheaper. The case of Timex emphasises how the strategy choices made by a multinational corporation in a constantly changing environment with elevated global competition, can detrimentally affect a local branch in an area such as Dundee. In this way, the organisation and identity of the local Timex plant changed dramatically over time, eventually leading to the bitter dispute and its closure in the early 1990s.

The implications of the dispute and plant closure for Dundee were deeply felt. 'Since 1947 the name of Timex had been synonymous with the name of Dundee' 10 but 'as jobs were cut, and despite long-established industrial procedures, several damaging disputes occurred ... which turned the national news spotlight on Dundee and, arguably, harmed the city's reputation'. ${ }^{11}$ The dispute and subsequent closure of Timex left the city reeling from the moral and financial implications of supporting a new batch of unemployed workers. At first the closure signalled a loss of hope and morale, as one of the apparently longstanding success stories of the city turned into a dramatic failure. This resulted in a dent in the city's new but still fragile image, and it was feared that other organisations would view Dundee as a trouble spot to be avoided, rather than as a place of opportunity. City officials feared that the negative publicity surrounding the dispute would affect the city's ability to attract other companies in the 
short term. However, the city council was determined to attract investment and refused to allow Timex's closure to defeat their development strategies. There was also fear about the effects that the closure would have on the people's morale. With employment opportunities falling, many former workers were encouraged to turn towards further education in order to improve their future prospects. With the increasing access provided to higher education, many former workers were given a new lease of life. However, despite these new opportunities, the closure of Timex did leave 'a hole in the heart of Dundee', as one citizen described it. Many workers felt devastated by the redundancies, as whole families once employed by Timex had lost their jobs.

The memory of Timex is still painful in the city, especially for those who suffered as a result of the closure. It was too bitter a dispute to put aside easily in view of the depth of hostility engendered. Some images of the dispute still linger on such as that of the 'scabs' with their covered faces being brought into the factory on buses through the jeering picket lines that featured so prominently in press reports. ${ }^{12,13}$ After 1993 and the dispute and subsequent closure of the Timex plant, other multinational industries in Dundee such as NCR, based on a similar medium technology model, felt equally threatened. They began to 'downsize' as multinationals found it more profitable to relocate in other areas such as those in Southeast Asia favoured by Timex. NCR was under a threat throughout the 1990s that was similar to that which faced Timex. However, after this period of uncertainty, there was a turning point in September 1999, when NCR announced a 20 million pound investment for 500 staff on a research and development centre in Dundee. The storm had been weathered and the end of the 1990s appeared to bring new hope to the city.

\section{RE-IMAGING DUNDEE: POST-INDUSTRIAL STRATEGIES}

The decline of Dundee's industries seemed to stimulate officials, leading figures in the private business community and other concerned individuals in the city to explore new development strategies. The first tentative attempts to change Dundee's image had, in fact, been made as far back as the 1930s and again in the post-war period when the decline of the jute industry in the city began to be felt. However, it was not until the 1980s that a sustained attempt was made to change the city's image of noisy textile mills, smoking factory chimneys and slum tenement housing to one more compatible with a hoped for 'high-tech' future. ${ }^{9}$ The re-imaging of the city did not fully take place until after its decline as a manufacturing centre at the end of the 20th century. Deindustrialisation in Dundee was evident in other typical features of the process besides the decline in the output of manufacturing industries and losses in skilled, semi-skilled and unskilled work. Increased levels of unemployment, especially among young men, and relatively low average income levels were accompanied by the associated migration of labour out of the city. The continued depopulation of the city meant a reduction in the local tax base and increasing demands on health, welfare and social security benefits. The local physical environment deteriorated including an 
increase in vandalised housing, derelict factories and mills and other deserted buildings. The remains of the overcrowded, smoke-laden 'Juteopolis' are still evident. Hundreds of tenement blocks throughout the city add to the panoramic view from the top of 'The Law', the highest hill in Dundee. Although the atmosphere of the industrial era still prevails, the mill owners or 'jute barons' did provide a number of public buildings such as libraries as well as parks that also still remain in many parts of the city and, to some extent, counteract the dark, industrial heritage embodied in the mills and tenements.

Along with the continued industrial decline of the city, there were various attempts made by succeeding local administrations to solve the problems created by economic decline with efforts being made to reverse it. Poor housing quality especially in the council housing estates was seen as a major problem as was the need to prepare a plan for the redevelopment of the city centre. In the 1970s an industrial improvement area was designated within the city. A partnership was set up with Dundee District Council, Tayside Regional Council, the Scottish Development Agency and members of the local business community all being key players. This led to the Dundee Project being set up which from 1981 until 1991 co-coordinated economic development through a partnership approach in the city. The aim of the project was to transform Dundee into a leading location in Scotland for investment and development of industries and to explore the development of Dundee's potential as a tourism destination. Indeed, strategic priorities for tourism development were formed at sub-national rather than national levels in the UK, empowering decision makers in local areas like Dundee.

With the help of strategic planning through the Dundee Project, the city began to re-invent its image. In the 1980s, it was seen as ugly and drab, with the Victorian architecture of the city having been submerged under buildings of the 1960s and the shopping centre and visitor attractions all outdated with little to offer visitors. Indeed, filmmakers used the city square to represent scenes from Soviet Russia as the architecture was said to be so similar. The work of the Dundee Project, along with the return of the RRS Discovery to Dundee, was aimed at establishing the city as the 'City of Discovery' in order to change its image for the better, to transform its economy from a manufacturing base to a modern diversified one, and to put the city on the tourism map. At the time it was noted that: 'While it is probably fair to claim that Dundee's failure to establish itself as a significant tourist destination can be directly related to its industrial image, the city's industrial heritage can also be seen as offering a potential which can be exploited in developing Dundee's tourism potential'. ${ }^{14}$ Improvements had to be made in all areas of the city including facilities, attractions, services and image in order to turn Dundee from 'jute, jam and journalism' into the 'City of Discovery', a potential tourist attraction.

By the early 1990s the transformation of the city was well underway. One of the major regeneration projects that the Dundee Project, which by that time had evolved into the Dundee Partnership, had started was the ongoing environmental improvement of the city centre. Shopping was identified as playing an important part in the attraction of day visitors to 
Dundee. In the 1980s, due to the outdated and drab nature of the city centre, many companies and high street retailers were considering relocating elsewhere. For a long time the city centre was stuck in a 1960s 'timewarp', where shopping centres and shop fronts along with streets and pavements were left unchanged allowing them to fall into disrepair. Both the refurbishment of the Wellgate Shopping Centre and the completion of Discovery Point were achieved in 1993. The central Overgate shopping complex was completed in March 2000. With the help of these developments, it was hoped that Dundee would be recognised increasingly as an 'up and coming' visitor centre with a credible tourist base, and a city which encouraged research and development and academic excellence.

The post-industrial strategies of Dundee have involved a change in the economy's employment structure towards the tertiary sector in order to create more employment opportunities and to attract people, companies and above all capital to the area. There was also a reappraisal in the late 1980s and the 1990s of the low cost tenement housing in the city centre. Large tracts, which had not undergone demolition in the 1950s and 1960s, were planned for redevelopment in contrast to the earlier period when people were moved out of the city centre often to high-rise flats and council housing estates of the periphery. Attempts were made to modernise the city centre, not only for office/shopping purposes, but also to bring in residents through the conversion for residential purposes of former hotels, newspaper and other plants, stores and offices, and most of all, the former jute and linen mills. The city centre, in contrast to some of the neglected housing estates further out, is being made to look more attractive and people are being encouraged to make more use of its facilities. As with many other cities in the UK, the main streets are pedestrianised, with buses and cars being re-routed. More of a feature is also being made of historical sites, such as the Dundee city centre Howff Graveyard. Thus, the attempted transformation of the city from a manufacturing-based economy to a more diversified one, involves strategies not simply of diversifying its economic potential, but of changing the city's industrial image and replacing it with a new vibrant one. This is being done partly through an ongoing programme of urban regeneration. Dundee is being made into a new city of culture and history, a pleasant place to visit and to stay in, that is attractive to tourists and residents alike. This not only brings into the city students to the universities and colleges but also high quality staff for the new 'high tech' industries and for the research and teaching facilities. The city is being made more attractive as a cultural centre for middle class professionals who come to the city to work. However, they do not tend to look for residences in the city but rather to the neighbouring dormitory suburbs and villages such as Monifeith, Carnoustie or Invergowrie or even across the road bridge to the Kingdom of Fife. The city loses much revenue from those who work there but live elsewhere according to the city's former Lord Provost (a position similar in standing to Mayor), Mervyn Rolfe. The hope is that this will change with the attractions that the city centre now has to offer its residents. For example, the new 'cultural quarter' to the west of the centre, so-called due to the concentration of new cultural 
arts buildings, now features not only the renovated Dundee Repertory Theatre but also the recently built Dundee Contemporary Arts Centre (DCA) and the adjacent Dundee Science Centre, 'Sensation'.

Dundee's development strategies have therefore aimed not only to provide a new image of the city to the outside world but also to give it a new identity and its citizens more pride, confidence and hope for the future. The aim has been to encourage Dundonians as well as the outside world to forget the former images of Dundee associated with militancy and trade union activity, such as those presented in the Timex dispute. Technology, tourism and teaching (the three Ts) are the crucial elements in the new thinking about urban development and regeneration. They symbolise new hope for the city and the start of a new era in the new millennium. Thus, Dundee's strategies have been developed to include investment in tourism, sports, education, and especially the Universities and the establishment and development of institutions of more advanced technology. The strategies have the objective of attracting more commercial activities, capital and people as residents, clients and tourists. As a result, there has been an attempted evolution of the once 'single industry' city into one with a diverse local economy based on the provision of services and advanced technology. Time will reveal the ultimate success of this strategy.

\section{THE DUNDEE WATERFRONT: PLANS FOR FUTURE PHYSICAL REGENERATION AND ADAPTATION}

Dundee's industrial decline meant that the historic harbour and docks were no longer used to the same extent in the post-war era compared to when the city was a major centre for jute manufacture, an industry which had relied upon sea and rail transportation. ${ }^{7}$ Indeed, in the 1960s the historic central dock was in-filled to make way for the construction of the Tay Road Bridge with exits near the city centre. Although the original plans were for the road bridge to link directly with the Kingsway ring road to the east of the city, the choice of locating the bridge much closer to the heart of the city required the former central dock area to be converted into dry land to allow for the necessary road system and ramps. This area was used for further developments and construction such as the building of the Olympia Leisure Centre and Tayside House, a multistorey tower used as the site of Dundee City Council's executive headquarters. However, both these structures were originally planned as part of a much larger modernist development that was intended to create a multi-level civic and commercial centre. ${ }^{15}$ These plans were never realised in full and the resultant developments not only deviated from original intentions, but can also be seen as comprising ad hoc erections of individual structures rather than the implementation of a larger cohesive plan for an integrated area development. However, the most significant results of this process have been twofold.

First, the adaptations have led to a physical and visual severance of the waterfront area from the city centre. Secondly, there was a resultant barrier effect of the road bridge and the design of the inner ring road whereby access by a multitude of user groups tended to be restricted. 
Although there were two purpose-built pedestrian crossings, one leading to the railway station and Discovery Point Visitor Centre and the other to the Olympia Leisure Centre, the planning and overall design of access points to the waterfront area did not facilitate integrated and user-friendly access for pedestrians coming from the city centre. Instead the road layout surrounding the harbour forms the main entrance and exit points to the city by road and serves to encourage vehicle access to specific venues, such as the Olympia or Discovery Point, rather than flexible pedestrian usage of the waterfront area along the river. Therefore, developments to the original harbour area, a hugely significant part of the city's maritime heritage, have not led to the creation of a central Waterfront area that maximises its full potential or reflects the city's identity, both past and present.

Attempts are now being made to reinvigorate the area, to reduce the redundant nature of much of the space surrounding the Waterfront stretching between the rail and road bridges and to reintegrate the Waterfront with the city centre grid. In 1998 the Dundee Partnership, started to evaluate the various possible options for doing so. The Dundee Partnership was keen to maximise community benefit from the proposals ${ }^{16}$ and further enhance access from the Waterfront to the recently achieved nearby developments within the cultural quarter, the DCA, 'Sensation' and 'Dundee Rep'. With their proximity to Dundee and Abertay Universities, the plan was to break down existing physical barriers in order to bring the key institutions of the city together and to further stimulate the city's economic regeneration. After an initial consultation exercise in 2000, which was followed by an extended consultation process in 2001, the Dundee Partnership approved a final master plan to cover a period of phased implementation of the Waterfront Project over the next 30 years.

With funding from the Scottish Executive, the Master Plan for the major central Waterfront redevelopment therefore comprises of an extension of the city centre to the waterfront. This includes improvements to pedestrian, cycling and bus routes, creation of a new grid street pattern, attempts to reduce the negative effects of cars and parking, removal of some of the existing Tay Road Bridge ramps, the creation of a pair of east/west tree lined boulevards, a new civic space and re-opened dock, and a new rail station and arrival square. ${ }^{15}$ In addition, the proposals mean that the skyscraper on Dock Street, Tayside House will be demolished and the council will relocate to new premises elsewhere in the city. Thus far, developments have already begun with major work being carried out to the area adjacent to the rail station and demolition of one of the existing pedestrian crossings originally erected in the 1960s.

While many embrace these proposals, there is acknowledgment that previous briefs put forward for the development of the central Waterfront area have had limited success. For instance, the 1984 Scottish Development Agency brief ${ }^{17}$ outlined plans for the area to be developed for various uses comprising mixed leisure, commercial and residential purposes. Although some of the original plans have been realised in the interim, such as the 'flagship' tourism attraction in the form of Discovery Point, other recommendations of the plan were not implemented. For 
instance, the plan advocated that the area be developed in an integrated fashion and that it would be undesirable to allow planning approval for food superstores. The former characteristic did not materialise with resultant projects proving ad hoc and were largely unrelated in design/ planning to other developments taking place. The latter was also ignored and there now exist a number of large-scale retail superstores and corresponding car parking areas. Therefore, most of the brief's original aims were either ignored or not realised, and were seen as a missed opportunity for planned regeneration, ${ }^{17,18}$ further delaying the process until recent years and the apparent consensus achieved by the Master Plan in 2001.

The opportunities represented by largely disused port areas located in close vicinity to large urban settlements and central business districts (CBDs) are indeed many. ${ }^{19,20}$ However, as well as enthusiasm for the proposed plans, based on past experience it would appear to be wise to also adopt a degree of caution towards these more recent attempts at waterfront development. Moreover, focus needs to be paid to the reiterated requirements for integrated development that would encourage a range of users and usability. This should link the waterfront to the city centre and avoid any tendency to focus exclusively on the Waterfront development, which could result in engraining the existing detachment between the two zones. ${ }^{18}$ There should be an avoidance of over-reliance upon singular concepts or predominantly consumption-based strategies such as retail that may suffer from long-term vulnerability to outside competition, a feature that has historically blighted the success of Dundee's industries and economic growth.

\section{CONCLUSION}

Development strategies, initiated in the 1980s and spurred on by the demise of the jute industry, heralded in the 1990s a period that was to be marked by further changes in orientation for the city especially following the closure of Timex in 1993. The post-World War II era, where strategies encouraged multinational industries with middle level technologies to come to the city, drew to a close in line with new multinational global strategies aimed at relocating industries to areas such as Southeast Asia. It was mainly after the closure of Timex in Dundee that increased efforts were made to break with the past. The negative publicity that resulted from the media reports on the Timex dispute, indeed assured a more fundamental seriousness of purpose in the subsequent attempts that were being made in the city to embark upon new post-industrial strategies. These involved an increased commitment to the development of 'high tech' industries and research institutes linked with higher education teaching. They also involved a reorientation away from manufacturing to tertiary industries such as those involved not only in teaching and research, but also in health-related services and tourism. The Timex dispute involved a bitter but also a symbolic break with Dundee's industrial past and gave an almost desperate energy to those who wished to save the city and negate media predictions of 'gloom and doom'. There was a new determination among Dundee's leading citizens that the city 
should not be seen in the light that had shone on it nationwide in the headlines of the Timex dispute. If the tide of decline was to be reversed in Dundee, and if it was to survive, grow and prosper, then it could no longer be seen as Scotland's forgotten city mired in the past. Instead, the images of Dundee's past have been selectively adapted for present and future needs. Thus, the Waterfront Development, which is based on its former maritime heritage, will turn Dundee's gaze once more to the sea and hopefully make the city more attractive to residents and tourists alike. In this way, the city is being dramatically re-imaged and restructured, adapting to changed social, economic, and political conditions. Service industries in the new Dundee have replaced past secondary manufacturing industries. Following the collapse of jute and the demise of Timex, the service sector has become the new focus of growth. The danger is that certain aspects of the city's history will be ignored, while, with the distancing of time, others will become distorted or at least sanitised for contemporary consumption. It is important to be aware of the past in order to avoid the same pitfalls. Thus, it is necessary for those in leadership positions in Dundee, like all Dundonians, to be aware of the dangers of a lack of diversification in future developments involved in projects like the Dundee Waterfront so that similar mistakes made in the past will not be repeated in the future.

\section{References}

1. This paper was previously published in 2007 as 'Heritage and Urban Renewal in Dundee: Learning from the past when planning for the future of a post-industrial city', in C. Aitchison, G. Richards and A. Tallon (eds) 'Urban Transformations: Regeneration and Renewal through Leisure and Tourism' (LSA Publication No. 96). Eastbourne: Leisure Studies Association, pp. 115-128.

2. Beveridge, C. \& Turnbull, R. (1997). Scotland after Enlightenment, Polygon, Edinburgh.

3. Di Domenico, M. (2001). Brand images of place and new urban identities in Scotland, in Horne, J. (ed.) Leisure, Cultures, Consumption and Commodification, LSA Publication No. 74, Leisure Studies Association, Eastbourne, pp. 81-92.

4. Walker, W.M. (1979). Juteopolis: Dundee and its Textile Workers 1885-1923, Scottish Academic Press, Edinburgh.

5. Whatley, C. (1992). The making of 'Juteopolis' — and how it was in Whatley, C. (ed.) The Remaking of Juteopolis: Dundee Circa 1891-1991, Publication No. 32. Abertay Historical Society, Dundee, pp. 7-22.

6. Harvie, C. (1981). No Gods and Precious Few Heroes: Scotland 1914-1980, Edinburgh University Press, Edinburgh.

7. Ogilvy, G. (1993). The River Tay and its People, Mainstream Publishing, Edinburgh.

8. Dundee Advertiser, 22nd December 1906, quoted in 4.

9. Doherty, J. (1992). Dundee: A post industrial city in Whatley, C. (ed.) The Remaking of Juteopolis: Dundee Circa 1891-1991, Publication No. 32. Abertay Historical Society, Dundee, pp. 24-39.

10. Anon (1993). Council agrees to offer Timex help. The Courier and Advertiser, Dundee, 26th February.

11. Anon (1993). Times good and bad for Timex. The Courier and Advertiser, Dundee, 16th February.

12. Anon (1993). Tick-a-tick Timex time's running out. The Guardian Week-End, Manchester, 29th May.

13. Anon (1993). Timex Dundee's dispute. The Economist, 29th May.

14. DCC, Dundee City Council (1989). Economic Development Plan-1989, Dundee City Council, Dundee.

15. DCC, Dundee City Council (2005). Dundee Central Waterfront: Development Master Plan 2001-2031, Dundee City Council, Dundee.

16. Fernie, K. \& McCarthy, J. (2001). Partnership and community involvement: Institutional morphing in Dundee. Local Economy. 16(4), 299-311. 
17. McCarthy, J. (1995). The Dundee waterfront: A missed opportunity for planned regeneration. Land Use Policy. 12(4), 307-319.

18. McCarthy, J. (1998). Waterfront regeneration: Recent practice in Dundee. European Planning Studies. 6(6), 731-737.

19. Pinder, D. (2003). Seaport decline and cultural heritage: Sustainability issues in the UK coastal zone. Journal of Cultural Heritage. 4(1), 35-47.

20. Pinder, D., Hoyle, B. \& Husain, S. (1994). Retreat, redundancy and revitalisation: Forces, trends and a research agenda, in Hoyle, B.S., Pinder, D.A. and Husain, M. (eds) Revitalising the Waterfront: International Dimensions of Dockland Redevelopment, Wiley, New York, pp. 247-260. 